\title{
Dermoscopy of a solitary storiform collagenoma
}

\author{
Mona Ebadian $^{1}$, Luigi Citarella ${ }^{1}$, Damian Collins $^{1}$, Salvador Diaz-Cano ${ }^{2}$, Lucia Pozo-Garcia ${ }^{1}$
}

1 Lewisham and Greenwich NHS Trust, London, UK

2 Kings College Hospital, London, UK

Key words: collagenoma, storiform collagenoma, sclerotic fibroma, Cowden syndrome

Citation: Ebadian M, Citarella L, Collins D, Diaz-Cano S, Pozo-Garcia L. Dermoscopy of a solitary storiform collagenoma. Dermatol Pract Concept. 2018;8(2):120-122. DOI: https://doi.org/10.5826/dpc.0802a09

Received: January 16, 2018; Accepted: February 20, 2018; Published: April 30, 2018

Copyright: @2018 Ebadian et al. This is an open-access article distributed under the terms of the Creative Commons Attribution License, which permits unrestricted use, distribution, and reproduction in any medium, provided the original author and source are credited.

Funding: None.

Competing interests: The authors have no conflicts of interest to disclose.

All authors have contributed significantly to this publication.

Corresponding author: Lucia Pozo-Garcia, MD, PhD, Lewisham and Greenwich NHS Trust, Stadium Road, London, Greater London, SE18 4QH, United Kingdom. Tel.+44 2088365261 Fax.+44 20 88366935. Email: lpozo@doctors.org.uk

ABSTRACT The dermoscopic features of solitary storiform collagenomas (sclerotic fibromas) have not been described previously, as these are rare cutaneous soft tissue tumors. The presence of multiple lesions is considered a marker of Cowden syndrome. They can also present as single firm cutaneous nodules. We present an unusual single nodule with distinct dermoscopic and histologic features.

\section{Case Presentation}

A 44-year-old fair-skinned male presented with a several-year history of a slowly enlarging asymptomatic nodule on his right forearm. He had an extensive sun exposure history and prior history of basal cell carcinomas but was otherwise in good general health. There was no family history of cancer.

The physical examination revealed a $1 \times 1 \mathrm{~cm}$ solid, wellcircumscribed, white, firm nodule on the extensor aspect of his right forearm (Figure 1).

Dermoscopy showed a homogeneous white background with some peripheral arborizing vessels and mild erythematous halo (Figure 2). A complete excisional biopsy was performed. Histology revealed a well-circumscribed polypoid lesion covered by an atrophic epidermis. The dermis contained sclerotic bundles of collagen with a storiform pattern and scattered fibroblasts; no collagen bundles with plywoodlike or concentrically lamellar pattern were identified. No depressed surface, dermal atrophy, infiltrative edges, vascular proliferation, dermal spindle-shaped or dendritic melanocytes were seen (Figure 3).

\section{Diagnosis}

Solitary storiform collagenoma (sclerotic fibroma)

\section{Discussion}

The solitary storiform collagenoma (sclerotic fibroma) is a rare benign soft tissue tumor presenting as a slowly enlarging well-circumscribed solid, fibrous, pink, white or flesh-colored papule or nodule in young and middle-aged adults of both sexes [1]. It is more commonly found on the face and limbs but has also been described on the scalp, trunk, oral mucosa and nail bed [2]. The presence of multiple storiform collagenomas is considered as a cutaneous marker of Cowden syndrome [3]. Histology of sclerotic fibromas reveals a wellcircumscribed non-encapsulated dermal nodule with hypocellular storiform collagen bundles showing prominent clefts [4], sometimes with accumulation of collagen bundles in biphasic growth and arranged in a plywood-like or concentrically lamellar patterns [5]. 


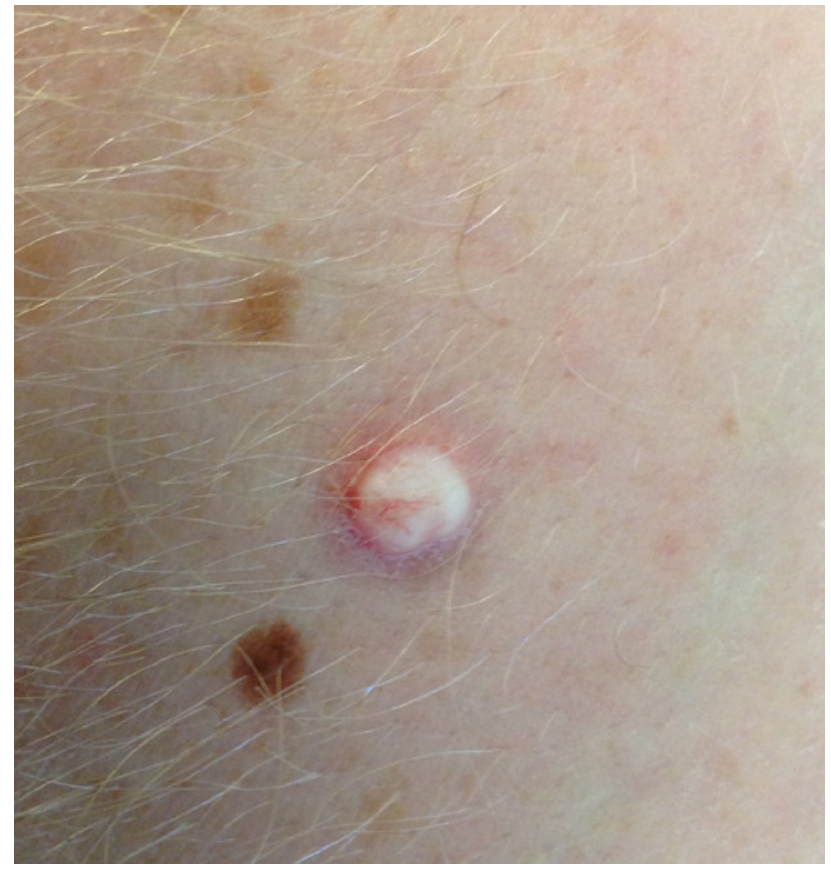

Figure 1. Well-circumscribed, white, firm nodule with erythematous halo and superficial vascularization. [Copyright: (02018 Ebadian et al.]

We present an unusual solid, single nodule in a fairskinned patient with prior history of basal cell carcinomas. Dermoscopy showed a homogeneous white background

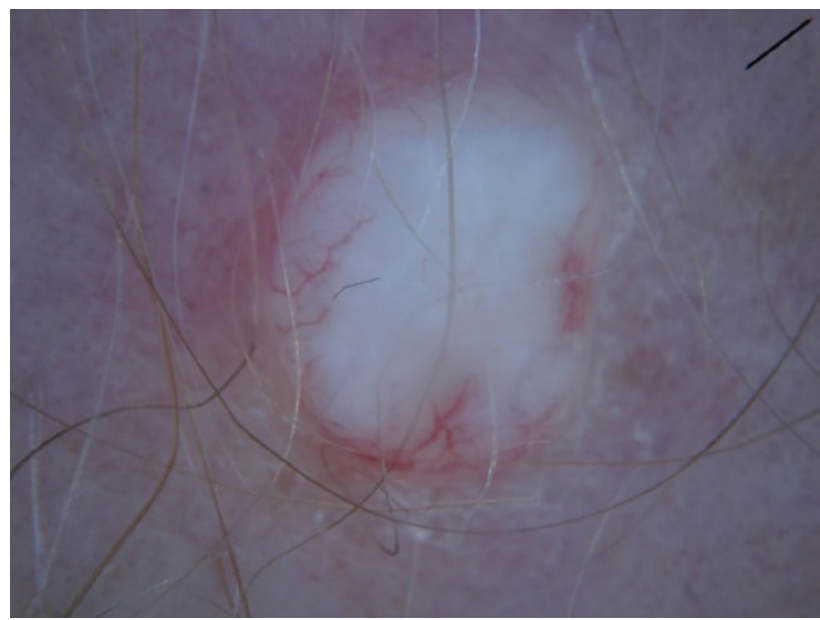

Figure 2. Dermoscopy shows a homogeneous structureless white lesion with erythema and arborizing vessels in peripheral distribution (polarized contact dermoscopy, x10). [Copyright: (02018 Ebadian et al.]

with peripheral arborizing vessels; this pattern has not been described previously. Some atypical forms of dermatofibromas [6], late stages of sclerotic dermatofibromas and amelanotic blue nevi, may occasionally present with similar dermoscopic features [7]. A sclerotic fibroma-like dermatofibroma has also been described as an uncommon variant of dermatofibroma [8]. It is unclear if storiform collagenomas represent

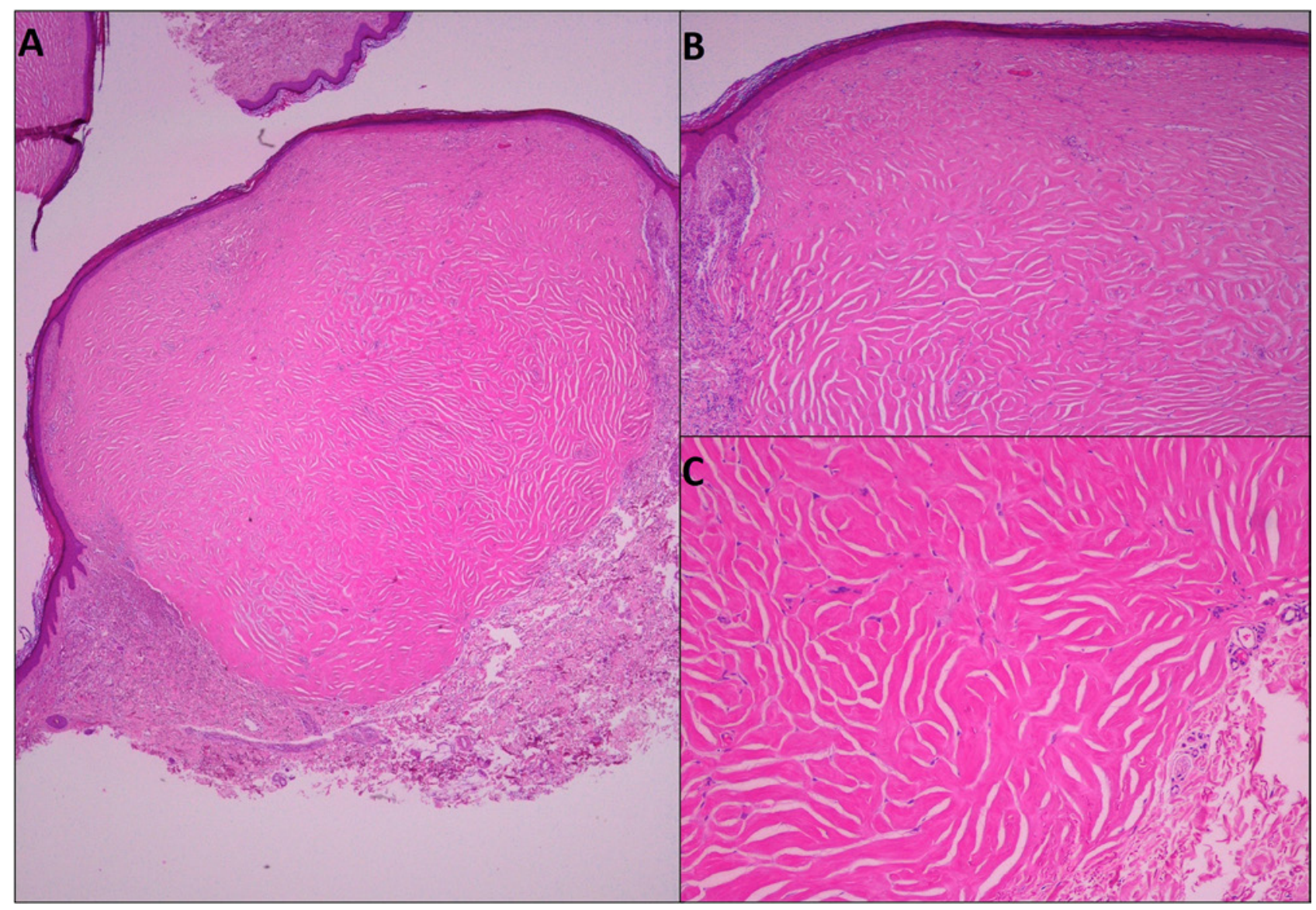

Figure 3. Well-circumscribed polypoid lesion contained collagen bundles separated by prominent clefts with scattered fibroblasts. Hematoxylin-eosin stained sections (A. 40x, B. 100x, C. 200x). [Copyright: @2018 Ebadian et al.] 
a fibrous tissue hamartoma or a genuinely fibrohistyocitic neoplasm; some storiform collagenomas may correspond to involuting dermatofibromas [9]. Storiform collagenomas should be considered in the differential diagnosis of acquired white firm papules or nodules. Histology is needed to confirm the diagnosis.

\section{References}

1. Metcalf JS, Maize JC, LeBoit PE. Circumscribed storiform collagenoma (sclerosing fibroma). Am J Dermatopathol. 1991 Apr;13(2):122-129.

2. Tosti A, Cameli N, Peluso AM, Fanti PA, Peserico A. Storiform collagenoma of the nail. Cutis. 1999 Sep;64(3):203-204.

3. Al-Daraji WI, Ramsay HM, Ali RB. Storiform collagenoma as a clue for Cowden disease or PTEN hamartoma tumour syndrome. J Clin Pathol. 2007 Jul;60(7):840-842.
4. Lo WL, Wong CK. Solitary sclerotic fibroma. J Cutan Pathol. 1990 Oct;17(5):269-273.

5. Nakashima K, Yamada N, Adachi K, Yoshida Y, Yamamoto O. Solitary sclerotic fibroma of the skin: morphological characterization of the 'plywood-like pattern'. J Cutan Pathol. 2008 Oct;35 Suppl 1:74-79.

6. Coelho de Sousa V, André Oliveira A. Nodular lesion with polymorphous vascular pattern. Dermatol Pract Concept. 2017;7(4):81-83.

7. Ma C, Chambers CJ, Kiuru M, Marsee DK, Silverstein M. Amelanotic blue nevus. JAAD Case Rep. 2017 Mar;3(2):93-94.

8. Gonzalez-Vela MC, Val-Bernal JF, Martino M, Gonzalez-Lopez MA, Garcia-Alberdi E, Hermana S. Sclerotic fibroma-like dermatofibroma: an uncommon distinctive variant of dermatofibroma. Histol Histopathol. 2005 Jul;20(3):801-806.

9. Donati P, Amantea A, Carducci M, Balus L. Sclerotic (hypocellular) fibromas of the skin. Br J Dermatol. 1991 Apr;124(4):395-396. 